\title{
СИНДРОМ ЕМОЦЙНОГО ВИГОРАННЯ - ОДИН ІЗ ПСИХОЛОГІЧНИХ ЧИННИКІВ НЕГАТИВНОГО ВПЛИВУ НА ЗДОРОВ'Я МЕДИЧНОЇ СЕСТРИ
}

\author{
В. В. Литвинюк, О. В. Лотоцька \\ Вінницький медичний коледж ім. акад. Д. К. Заболотного \\ ДВНЗ «Тернопільський державний медичний університет \\ імені І. Я. Горбачевського МОЗ Украӥни"
}

У статті розглянуто наявність різних симптомів синдрому емоційного вигорання у медичних сестер різних клінічних закладів м. Вінниці як одного із чинників негативного впливу на здоров’я та запропоновано заходи із його профілактики.

\section{BURNOUT SYNDROME - ONE OF THE PSYCHOLOGICAL FACTORS OF NEGATIVE INFLUENCE ON THE HEALTH OF A NURSE}

\author{
V. V. Lytvynyuk, O. V. Lototska \\ Acad. D. Zabolotnyi Basic Vinnytsia Medical College \\ I. Horbachevsky Ternopil State Medical University
}

The article considers the presence of different symptoms syndrome of emotional burnout in nurses of different clinical establishments of Vinnytsia as one of the negative factors affecting the health and proposed measures for its prevention.

Вступ. Проблема впливу професійної діяльності на особистість в останні роки набуває великої актуальності. Особливо вона є важливою для тих, хто працює у сфері «людина-людина» і в силу своєї професійної діяльності змушені багато та інтенсивно спілкуватись з іншими людьми. До них належать і медичні сестри. Дуже часто, якщо не постійно, вони потрапляють у стресові ситуації, що може негативно вплинути на стан їх здоров'я як соматичного, так і психічного.

Ще у 1974 р. Г. Фрейденбергер ввів науковий термін «синдром емоційного вигорання» та дав характеристику психічного стану людей, які перебувають в інтенсивному і тісному спілкуванні з багатьма людьми [1, 2]. За визначенням Всесвітньої організації охорони здоров'я, синдром емоційного вигорання (CEB) - це фізичне, емоційне або мотиваційне виснаження, яке характеризується порушенням продуктивності в роботі, втомою, безсонням, підвищеною схильністю до соматичних захворювань, а також уживанням алкоголю або інших психоактивних речовин для отримання тимчасового полегшення, що має тенденцію до розвитку фізичної залежності та в окремих випадках навіть суїцидальної

() В. В. Литвинюк, О. В. Лотоцька, 2016 поведінки [3]. Проведене міжнародною кадровою компанією опитування встановило, що в Україні кожний четвертий працівник стикається з цим синдромом, хоча більшість опитуваних про нього навіть не чули [1].

Основна частина. Передумовами розвитку CEB у медичного персоналу можуть бути як зовнішні, так і внутрішні фактори. До перших належать такі: хронічна напружена психоемоційна діяльність, дестабілізуюча організація роботи, підвищений рівень відповідальності, низька соціальна оцінка значимості праці, девальвація професійної самооцінки в процесі накопичення професійного досвіду, необхідність безперервного післядипломного розвитку тощо. Внутрішніми чинниками для розвитку CEB можуть бути інтенсивність та стиль спілкування людини, відповідність їі темпераменту виконуваній роботі, схильність до екстра- чи інтравертованості [4].

У розвитку СЕВ виділяють три основних стадії. Перша - нервове напруження, яке проявляється у забуванні якихось моментів, збої при виконанні рухових дій, «провалах у пам'яті» тощо. Ця стадія може тривати 3-5 років. Друга стадія - опір. При ній спостерігається зниження зацікавленості роботою, спілкування $з$ 
іншими (в тому числі і вдома, з друзями), збільшення апатії наприкінці тижня, поява стійких соматичних симптомів (немає сил, енергії, головний біль, «мертвий сон без сновидінь», збільшення числа простудних захворювань тощо), збільшення дратівливості. В цій стадії медсестра намагається уникати зайвого спілкування, щоб відмежувати себе від неприємних вражень. Тривалість другої стадії - в середньому 10-15 років. Третя стадія - власне, емоційне вигорання (виснаження). Характерним їі проявом є повна втрата інтересу до роботи і життя взагалі, емоційна байдужість, відчуття постійної нестачі сил [5].

Основними факторами, що безпосередньо впливають на виникнення CEВ у медичних працівників середньої ланки є: висока насиченість робочого дня, впродовж якого відбувається спілкування з людьми з різними захворюваннями; велика кількість різних за змістом і емоційним напруженням міжособових контактів; висока відповідальність при догляді за хворими та виконанні маніпуляцій; постійне спілкування з пацієнтами та колегами; конфліктні або напружені ситуації в спілкуванні з пацієнтами, які викликані недовірою, незгодою проведення обстеження чи лікування, що проявляються в різних формах відмови від подальшої співпраці [6, 7].

На сьогодні виділяють близько 100 симптомів, які пов'язані з виникненням синдрому емоційного вигорання. Але серед них варто виділити декілька груп ключових: фізичні (втомлюваність, безсоння, погіршення самопочуття, головний біль, роздратованість, прояви вегетативної дисфункції); емоційні (песимізм, цинізм, байдужість, депресія, почуття самотності й провини); поведінкові (імпульсивна поведінка, постійне бажання відпочити, байдужість до їжі, виправдання чи потяг до вживання тютюну, алкоголю); інтелектуальні (втрата інтересу до роботи, формальне виконання роботи, байдужість до нових ідей) та соціальні симптоми (втрата інтересу до дозвілля, соціальних контактів і соціальної активності, відчуття ізоляції, відчуття нестачі підтримки з боку родини та друзів) [8].

Враховуючи актуальність проблеми було проведено анкетування 150 середніх медичних працівників різних за профілем лікувальних закладів м. Вінниці з метою визначення рівня розвитку в них синдрому емоційного вигорання та статистична обробка отриманих у результаті опитування даних.

Всі опитані медичні працівники були жіночої статі

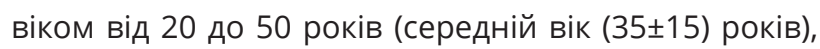
що за класифікацією ВООЗ належить до молодого та середнього віку.

Серед опитаних медичних сестер, як видно 3 рисунка 1, працювало у психіатричному відділенні $17(11,3 \%)$, неврологічному - 9 (6,0 \%), хірургічному 16(10,6\%), терапевтичному - 14 (9,3\%), лОР-відділенні 12 (8,0 \%),приймальному - 7 (4,6 \%), операційному 12 (8,0 \%), нейрохірургічному -13 (8,6 \%), реанімаційному - 15 (10\%),травматологічному - 10 (6,6 \%), фізіотерапевтичному -6 (4,0\%), гематологічному 9 (6,0 \%) та інших відділеннях - 10 (6,6 \%).

Негативний психологічний вплив на стан свого здоров'я та наявність клінічних симптомів СЕВ відчула більша половина медичних працівників. Позитивну відповідь дали 93 особи, що становило 62,0% всіх опитаних (рис. 2).

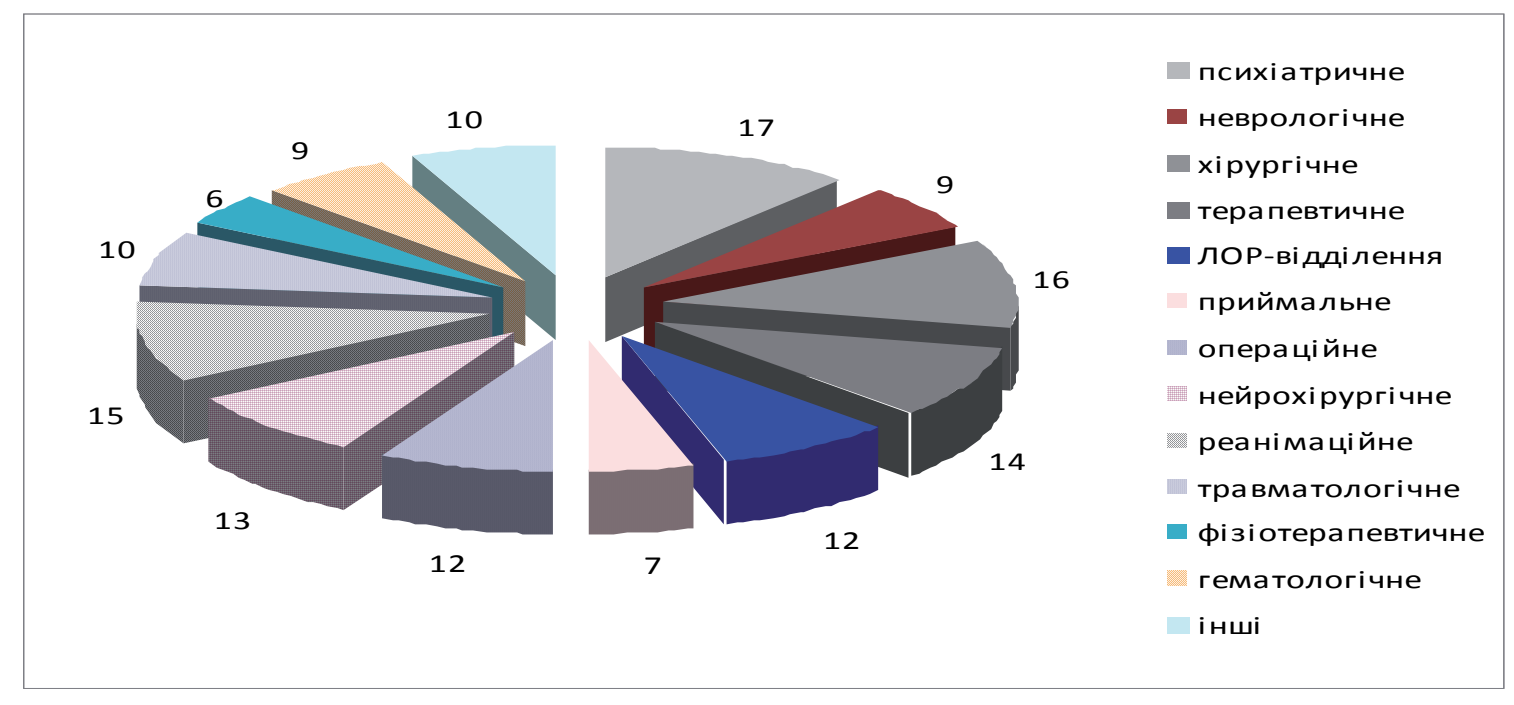

Puc. 1. Кількість опитаних медичних сестер за місцем роботи. 


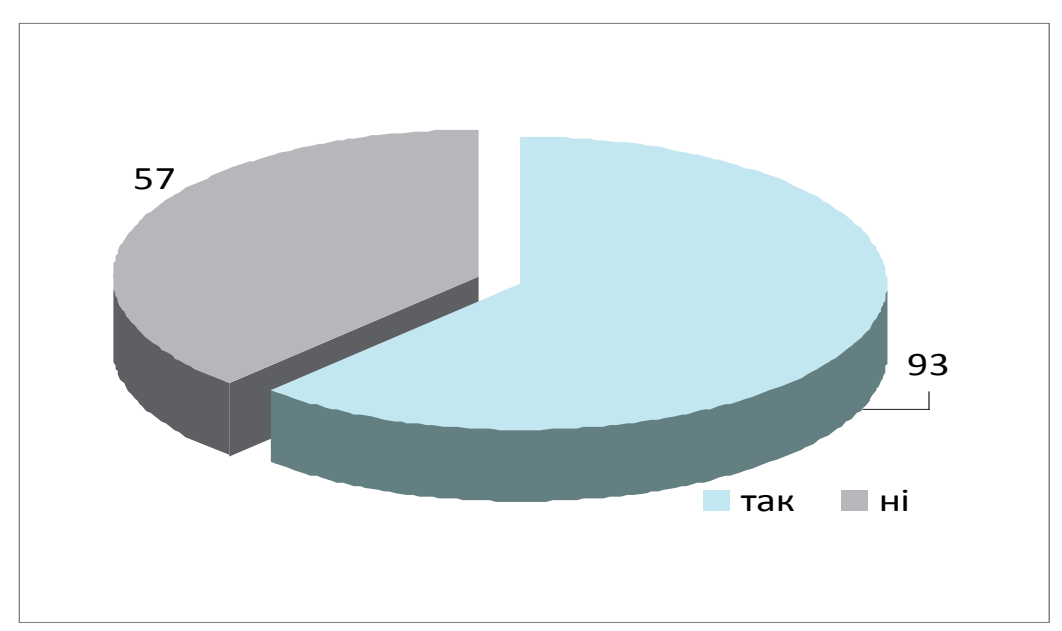

Puc. 2. Суб'єктивне відчуття наявності синдрому емоційного вигорання.

Зі всіх можливих симптомів, які характерні для CEB, ми вирішили вибрати такі: відчуття швидкого емоційного і фізичного виснаження або хронічної втоми, частий безпричинний головний біль, підвищена дратівливість на незначні події та запаморочення.

Симптоми, характерні для СЕВ і які найчастіше спостерігали у себе медичні сестри були головний біль 32 (34,4 \%), підвищена дратівливість - 30 (32,2 \%), запаморочення - 17 (18,2\%), швидка втомлюваність 10 (10,7%). Інші прояви, такі як байдужість до виконання професійних обов'язків, депресія, безсоння мали 4 особи (4,3\%) (рис. 3).

Також ми вирішили вияснити, які прояви CEB спостерігають у себе працівники різних відділень найбільше. Як видно з таблиці 1, найбільше скарг на підвищену дратівливість на незначні події висували медичні сестри нейрохірургічного $(76,9 \%)$ та приймального (71,4 \%) відділень.
Запаморочення найбільше спостерігали медики реанімаційного (46,6 \%) та ЛОР-відділень (41,6\%). На головну біль найбільше скаржилися працівники фізіотерапевтичного (66,6\%) та психіатричного (58,8\%) відділень. Швидка втомлюваність була в 56,2 \% медичних сестер хірургічного та 44,4 \% - неврологічного відділень.

Серед медичних сестер, які відчули погіршення у стані свого здоров'я, більше половини 52 (55,9 \%) опитаних усвідомлюють наявність проблеми та попереджають подальший розвиток синдрому емоційного вигорання різними шляхами. 21 особа $(45,1 \%)$ забезпечують собі позитивний настрій, 12 (12,9\%) - застосовують сон та відпочинок, 5 (5,3 \%) - полюбляють прогулянки на свіжому повітрі, 6 (6,4 \%) - займаються спортом, 8 (8,65 \%) приймають заспокійливі лікарські засоби. Але, на жаль, 41 медичний працівник (44,0 \%) нічого не робить для попередження розвитку синдрому емоційного вигорання (рис. 4).

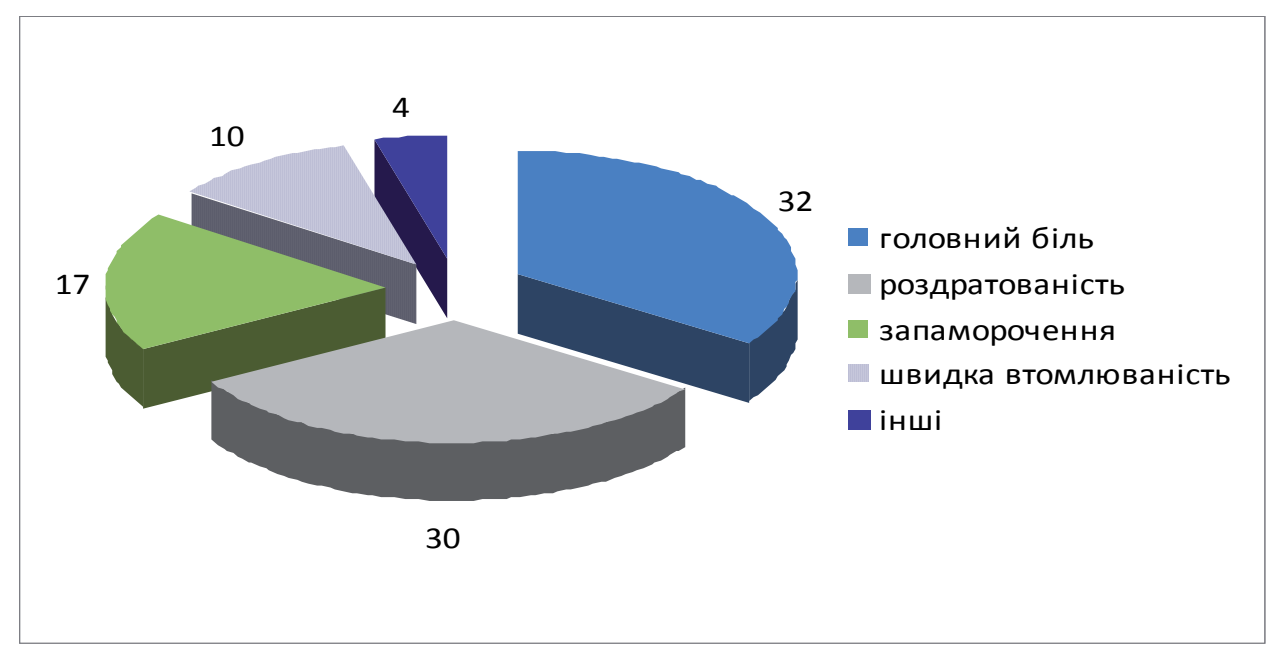

Puc. 3. Основні скарги медичних працівників з синдромом емоційного вигорання. 
Таблиця 1. Прояви симптомів синдрому емоційного вигорання

\begin{tabular}{|c|c|c|c|c|c|}
\hline \multirow[b]{2}{*}{ Клінічні відділення } & \multicolumn{5}{|c|}{ Симптоми } \\
\hline & $\begin{array}{c}\text { підвищена } \\
\text { дратівливість \% }\end{array}$ & запаморочення \% & $\begin{array}{c}\text { головний } \\
\text { біль \% }\end{array}$ & $\begin{array}{c}\text { швидка } \\
\text { втомлюваність }\end{array}$ & інш \\
\hline Психіатричне & 52,9 & 17,6 & 58,8 & 29,4 & 11,7 \\
\hline Неврологічне & 44,4 & 11,1 & 55,5 & 44,4 & 22,2 \\
\hline Хірургічне & 43,7 & 31,2 & 37,5 & 56,2 & 25,0 \\
\hline Терапевтичне & 42,8 & 14,2 & 28,5 & 35,7 & 14,2 \\
\hline ЛОР-відділення & 58,3 & 41,6 & 50,0 & 16,6 & 8,3 \\
\hline Приймальне & 71,4 & 14,2 & 42,8 & 28,5 & - \\
\hline Операційне & 33,3 & 16,6 & 41,6 & 16,7 & 8,3 \\
\hline Нейрохірургічне & 76,9 & 7,6 & 23,0 & 30,7 & - \\
\hline Реанімаційне & 40,0 & 46,6 & 33,3 & 20,0 & 13,3 \\
\hline Травматологічне & 50,0 & 40,0 & 40,0 & 20,0 & - \\
\hline Фізіотерапевтичне & 16,6 & 16,6 & 66,6 & - & - \\
\hline Гематологічне & 44,4 & 11,1 & 22,2 & 11,1 & - \\
\hline Інші & 20,0 & 20,0 & 40,0 & 30,0 & 10,0 \\
\hline
\end{tabular}
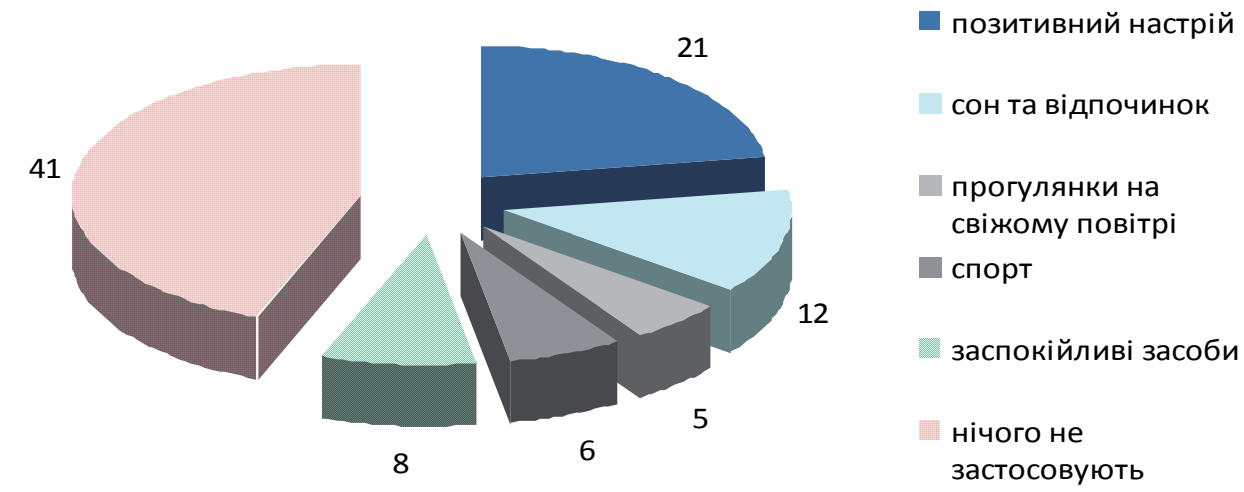

Puc. 4. Заходи профілактики емоційного вигорання.

Таким чином, згідно з Міжнародною класифікацією хвороб, СЕВ належить до рубрики Z73 - «Стрес, пов'язаний з труднощами підтримки нормального способу життя» [9] і його все частіше пов'язують зі станом передхвороби, яку можна і треба попередити.

3 метою профілактики негативного впливу психоемоційного фактора та попередження виникнення синдрому емоційного вигорання медичний персонал має дотримуватись рекомендацій, спрямованих на усунення дії чинників, які призводять до виникнення стресу, навчитись контролювати свої думки та емоції. Поліпшення умов праці, створення доброзичливих взаємовідносин у колективі, дотримання етичних та деонтологічних норм, уміння планувати свою роботу, позитивно мислити, уникати конфліктних ситуацій, змінювати світогляд - це те, що допоможе попередити емоційне вигорання.
На фізіологічному рівні позитивний ефект забезпечить: тривалий і якісний сон, збалансоване, насичене вітамінами і мінералами харчування, достатнє фізичне навантаження, заняття спортом, ранкова гімнастика, танці. Ефективним у даному випадку $\epsilon$ фітотерапія, гомеопатія, масаж, терапія кольором, ароматерапія, дихальні вправи, баня і водні процедури у вигляді контрастного душу та плавання.

На емоційному рівні ефективним буде спілкування з сім'єю, друзями, заняття улюбленою справою, хобі (книжки, фільми, в'язання, садівництво, рибальство, туризм тощо), прослуховування улюбленої музики, гумор, спілкування з природою, тваринами. Емоційне розвантаження забезпечить медитація, візуалізація, аутотренінг.

Одним із способів запобігання синдрому емоційного вигорання $є$ обмін професійною інформацією, що 
дає відчуття ширшого світогляду, ніж той, що існує всередині окремого колективу чи закладу, це забезпечать курси підвищення кваліфікації, конференції тощо.

Висновки. Існують різні думки щодо причин виникнення синдрому емоційного вигорання і самих його симптомів. Дослідники сходяться на думці про те, що головне основна проблема - взаємодія з людьми. Саме така взаємодія відбувається при ви-

\section{ЛІТЕРАТУРА}

1. Дослідження синдрому емоційного і професійного вигорання у фармацетичних працівників / В. О. Борищук, О. С. Соловйов, Т. М. Краснянська [та ін.] // Social pharmacy in health care. - 2015. - Vol. 1, No. 1. - C. 65-72.

2. Herbert J. Freudenberger Staff burn-out / J. Herbert // Journal of Social Issues. - 1974. - Vol. 30, № 1. - P. 159-165.

3. Доклад о состоянии здравоохранения в мире, 2001: психическое здоровье: новое понимание, новая надежда. - Женева : ВОЗ, 2001. - 178 с.

4. Колоскова О. К. Синдром емоційного вигорання у лікарів-педіатрів, які працюють на різному рівні надання медичної допомоги дітям / О. К. Колоскова, Т. М. Білоус, В. В. Білоус // Буковинський медичний вісник. - 2013. Т. 17, № 4 (68). - С. 79-82. конанні професійних обов'язків середнім медичним персоналом. Більшість опитаних відмічає негативний вплив психоемоційного чинника на своє здоров'я та має високий ризик виникнення синдрому емоційного вигорання. Своєчасне виявлення та попередження стресу, дотримання рекомендацій, застосування способів і засобів профілактики значно знизить ризик виникнення синдрому в медичних сестер.

5. Городовіченко В. М. Емоційне вигорання - плата за співчуття / В. М. Городовіченко // Медсестринство. - 2013. № 3. - С. 30-33.

6. Ізард К. Е. Психологія емоцій / К. Е. Ізард // Синдром емоційного вигорання. - СПб. : Питер, 2010. - 464 с.

7. Профілактика синдрому професійного вигорання у педагогів [Електронний ресурс]. - Режим доступу : http:// dorobok.edu.vn.ua/article/view/1257

8. Батюх О. В. Синдром емоційного вигорання у медичних сестер / О. В. Батюх // Медсестринство. - 2011. № 1. - C.11-13.

9. World Health Organization. The ICD-10 Classification of Mental and Behavioral Disorders: clinical descriptions and diagnostic guidelines. Geneva: WHO. 1992.

Отримано 31.03.16 